\title{
Hair in Exile: Manifestations of Displacement, Difference, and Belongingness through Hair in Chimamanda Ngozi Adichie's Americanah
}

\author{
Shuchi ${ }^{1} \&$ Josephine Ramdinmawii Zote ${ }^{2}$ \\ ${ }^{1}$ Assistant Professor, Department of Basic Sciences and Humanities and Social Sciences, National \\ Institute of Technology Mizoram, shuchi.nitmz@gmail.com ,ORCID- oooo-0oo2-8490-3631 \\ ${ }^{2}$ Research Scholar, Department of Basic Sciences and Humanities and Social Sciences, National \\ Institute of Technology Mizoram, joseyhearts@gmail.com, ORCID-oooo-00o2-2368-3436
}

\begin{abstract}
One familiar phenomenon that is often found in diasporic identities is the preconceived idealization of their host lands prior to their displacement. Once disillusioned from this fantasy, the realities of their inhospitable surroundings set in, and a grave sense of displacement and nostalgia for their homelands continue to materialize. Such people often seek for a sense of home and communal consciousness connected to their homelands. In the case of Chimamanda Ngozi Adichie's Americanah (2013), this connection manifests, and is explored by the protagonist, principally through hair. Americanah (2013) guides us through the discovery of, and inquiry into, the intricacies of race, gender, and identity by Ifemelu with her venture into a host country whose social and political history has put in front of her an unfamiliar identity to adopt. This paper attempts to trace the protagonist's experiences of displacement and existence in relation to the dominant community in her host country, as well as her discovery of a symbolic community where she adopts a new form of communal consciousness. Through a narrative that takes us back and forth different continents, showing us the difference between what it is like to be black in Nigeria and in America, Adichie shows us the impossibility to successfully encapsulate heterogeneous identities into an all-encompassing category of race. This paper explores the dynamics of differences as projected through the issue of identity with an emphasis on the subject of hair politics in Americanah (2013).
\end{abstract}

Keywords: Displacement, hair, diaspora, home, race, identity.

\section{Introduction}

One of the most influential African Anglophone writers of today, Chimamanda Ngozi Adichie has produced a wide range of stories centred, for the most part, in Africa. As a Nigerian native, her works explore the intricacies of ethnic identities, gender, culture, and religion in Nigeria, as well as in relation to the rest of the world. In her book Americanah (2013), Adichie delves into the psychological journey of a Nigerian student who discovers the complexities of race in America. The narrative method, travelling through time and continents, juxtaposes the protagonist Ifemelu's experience in the new host country with one in her homeland. Riddled with a disillusionment from the idealised America, the sense of displacement in an alien world, as well as discovery of personal identity, community, and belongingness, this novel reveals diasporic experiences that challenge the notion of the inviting, seemingly ideal world. The most eminent apparatus through which these concepts are explored in the novel is the subject of hair, particularly that of black women's hair.

(c) AesthetixMS 2020. This Open Access article is published under a Creative Commons Attribution Non-Commercial 4.0 International License (http://creativecommons.org/licenses/by-nc/4.o/), which permits non-commercial re-use, distribution, and reproduction in any medium, provided the original work is properly cited. For citation use the DOI. For commercial re-use, please contact editor@rupkatha.com. 
Hence, an inquiry into the world of hair politics and its history in America, paralleled with the lived experiences and discourse between the characters in the novel, is imperative to the study of these themes.

As a complex and contested term with multiple, often contradictory, theorisations, the meaning of the term "diaspora" has gradually been shifted overtime. According to Safran, it "seem increasingly to be used as metaphoric designations for several categories of people - expatriates, expellees, political refugees, alien residents, immigrants, and ethnic and racial minorities"(83). However, within the multiple contestations of what the term encompasses, the common concepts of displacement, longing, and return are given prominence. Upon entering America, Ifemelu has her life overturned by circumstances that were never part of the America she knew in Nigeria, the America where she "saw herself in a house from The Cosby Show, in a school with students holding notebooks miraculously free of wear and crease" (Adichie, 99).

Amidst tiresome political unrest and recurring strikes thwarting her education, Ifemelu turned to America for a promising and hopefully seamless future, only to have her seemingly auspicious host country unravel to reveal a desolate and unfamiliar ordeal. Her disillusionment began right after she entered the country and saw the buildings and signboards all "disappointingly matt"(Adichie, 104) and was made to sleep on the floor of her aunty Uju's house, because "in the landscape of her imagination, the mundane things in America were covered in high-shine gloss"(Adichie, 104) and even though she wouldn't mind sleeping on the floor in Nigeria, she was in "glorious America at last, and she had not expected to bed on the floor" (Adichie, 106). According to Fouad Mami, "uncritical exposures to Hollywood movies, cartoons and TV documentaries at home, translate in massive circulation of pipe dreams and empty promises for a better life. As a result, almost all Nigerians are transformed into potential immigrants" (Mami, 2). The ideal America that Ifemelu grew up familiarizing through movies and documentaries is eventually replaced by the real, dull and alienating one, where she discovered the weight of her identity as a black woman.

Finding herself lost in an unfamiliar host country with a deeply-rooted and complex power dynamics that inherently disfavours her very being, Ifemelu's sense of identity and dignity slowly disintegrated. She even went through depressive episodes, which she had always thought was only for Americans "with their self-absolving need to turn everything into an illness" (Adichie, 157). With return not being an option for her, Ifemelu eventually learned to find some sense of home and belongingness in America. She eventually adapted, to a certain degree, into a society where she had to learn that certain words and actions carry completely different meanings and weights. She decided to express the various observations and discoveries she made along the way on a blog titled "Raceteenth or Various Observations About American Blacks (Those Formerly Known as Negroes) by a Non-American Black" (Adichie, 4).

This blog became a mouthpiece through which she juxtaposes the experiences of being black in America to that of being black in Nigeria, the platform where she explores the complex social and cultural history of race in America that makes her blackness fundamentally different from that of African Americans. It also served as a device through which she found a community of people with shared experiences and sentiments, and a sense of home away from home.

\section{Redefining Identity}

As someone who has come from a place where difference was measured through ethnic identity to a place like America where differences are determined by racial identity, Ifemelu was confronted 
with the need to go through a process of identity formation that forefronts her race. A significant part of this process is constituted by the inquiry into the apparent policing of black hair, especially that of black women's. While hair had already been a consequential part of her identity, its role became much more complex and prominent once she made her way into the American society. While racial persecution and the history of the white man's transgression towards other races isn't unique to America, its long history of slavery and racial segregation, whose spirit continues to live on till today, had woven a complex web of inequity and conflict that cannot be ignored. Ever since the beginning of the enslavement of West Africans, the Europeans have always asserted their power through hegemonic exploitation of the slaves' hair.

The slave traders would shave the head of the slaves seemingly as a sanitary measure, but this shaved head, according to Ayana Byrd and Lori L. Tharps, "was the first step the Europeans took to erase the slave's culture and alter the relationship between the African and his or her hair" (10). Centuries after black hair was shunned and used to dehumanize and strip off the cultural identities of slaves, black hair is still subjected to constant degradation till today. Even after the end of the physical reign over black hair, a Eurocentric yardstick for measuring physical attributes has still continued to depreciate the very nature of blackness by accepting and glorifying fair skin and silky straight hair over dark skin and kinky hair.

This continued devaluation and dehumanization of blackness has created an internalization of the existent social hierarchy, propelling black people to reject their blackness. Ayana Byrd and Lori L. Tharps note, "(t)o gain access to the American dream, one of the first things Blacks had to do was make White people more comfortable with their very presence." (26). In order to survive in a world where they were involuntarily exiled, deprived of their cultural and ethnic roots, assimilation into the American society seemed like the only possible recourse. This resolution focused on physical image prompted an increasing demand for hair products specifically designed for black hair. In late 180o's and early 1900's, the black hair care industry saw a massive growth as pioneers like Madam CJ Walker and Annie Turnbo Malone started developing their straightening line. With these innovations, "African American women were more easily able to achieve a style that they felt would afford them greater social and economic mobility." (Johnson, and Bankhead $88)$.

However, these new set of products include chemicals that could potentially be extremely harmful and damaging. Risking burns and damage to one's hair and body seemed like a small price to pay for a socially acceptable "well-kept" image. While products like Madam C.J.Walker's straightening comb was created for "(b)lacks to feel pampered and cared for and be given the opportunity to experience beauty ritual" (Johnson, and Bankhead 88), the socio-cultural environment that created a need for black people to appear as non-threatening 'American' problematized even this seemingly innocent process.

As Ifemelu familiarized herself with the American society, she realized the weight her natural hair carried. Not long after her arrival, her Aunt Uju told her how she had to take her braids out and relax her hair for her interview, because according to her, natural hair in America was deemed "unprofessional" and when you "are in a country that is not your own...(y)ou do what you have to do if you want to succeed." (Adichie, 119). Though she found this absurd at the time, when she was told by Ruth to "(lose) the braid and straighten (her) hair" (Adichie, 202) for her own interview some years later, she "knew enough" (Adichie, 203) not to dismiss it and thanked her, because she had been acquainted to the American society enough to know that Ruth was right when she said "Nobody says this kind of stuff but it matters" (Adichie, 202). 
In her blog, she expressed her observation that hair seemed like "the perfect metaphor for race in America" (Adichie, 297) upon discovering the fact that her white friend was completely oblivious to the nature of black hair. In an interview, Adichie explains how hair can be a metaphor for race, because oftentimes even well-intended people are ignorant of the complexities of race like they are of black hair, she states, "Hair is something we see, but we don't understand what's behind it, kind of like race. It's the same way that something seems obvious, but it is really complicated and complex... sometimes the way that your hair grows from your head isn't considered 'professional' by people who don't know black hair. I don't think it's that people are malicious, I think it's just some people don't know what the hair that grows from the head of black women actually looks like" (Adichie interviewed by Ashley Weatherford).

According to Ayana and Tharps, while there are multiple types and textures of African hair, "the one constant Africans share when it comes to hair is the social and cultural significance intrinsic to each beautiful strand" (1); in spite of their many differences, lived experiences of a hair texture that is unique to them binds the people together. While it would be fallacious to analyze certain groups as monoliths, it is important to acknowledge that shared features and aspects of identity may unite dispersed identities, especially when existing as an "other" in relation to a dominant group. Understandably, it is through hair that Ifemelu was able to find a sense of home in America. When she suffered severe damage to her hair and scalp from relaxer burns, she was encouraged by Wambui to cut her hair and go natural, because according to her, "(r)elaxing your hair is like being in prison. You're caged in. Your hair rules you...You're always battling to make your hair do what it wasn't meant to do" (Adichie, 208).

Even though Ifemelu struggled to come to terms with her short hair, she eventually found comfort in an online natural hair community at 'HappilyKinkyNappy.com', a community of women who "were done with pretending that their hair was what it was not, done with running from the rain and flinching from sweat" (Adichie, 212). The women here have rejected Eurocentric norms and have "sculpted for themselves a virtual world where their coily, kinky, nappy, wooly hair was normal" (Adichie, 212). It is within this space that Ifemelu found what Clifford describes as the "(form) of community consciousness and solidarity that maintain identifications outside the national time/space in order to live inside, with a difference" (Clifford, 308). With this new-found affinity and support, "on an unremarkable day in early spring...she looked in the mirror, sank her fingers into her hair, dense and spongy and glorious, and could not imagine it any other way. That simply, she fell in love with her hair" (Adichie, 213).

It is also her hair that led her to 'Mariama African Hair Braiding' where she enters into a world that is reminiscent of a microcosm of Africa, located "in the part of the city that had graffiti, dank buildings and no white people" (Adichie, 9), where she was welcomed with a smile by Halima, one of the braiders, with "a smile that, in its warm knowingness, said welcome to a fellow African". (Adichie, 11). While the women there were from different parts of Africa, they have found themselves in a symbolic community established on the basis of shared experiences of living in America. According to Palmer, "(t)he modern African diaspora, at its core, consists of the millions of peoples of African descent living in various societies who are united by a past based significantly but not exclusively upon 'racial' oppression and the struggles against it; and who, despite the cultural variations and political and other divisions among them, share an emotional bond with one another and with their ancestral continent; and who also, regardless of their location, face broadly similar problems in constructing and realizing themselves" (Palmer, 30).

Palmer identified five major divisions of African diaspora where the latter two streams are constituted by those displaced by the Atlantic slave trade and those who have resettled after the 
abolition of slavery, respectively. While the experiences of people belonging to these two separate streams may vary significantly, in a socio-cultural context where their blackness is given precedence, this very element may act as a unifying factor. For Ifemelu, the path towards this community of African Diasporas is ushered by her struggle with owning a hair texture that was displaced. It is this aspect of her identity that is confronted with rejection and marginalization from the host community which unified her with other people of African descent living in America.

\section{Conclusion}

While Americanah (2013) may give an account of the protagonist's personal struggle and reconciliation with her hair, it is important to note that varied experiences and psychological makings of multiple identities may produce significantly differing attitudes toward hair. While Ifemelu's journey is significant in analyzing modern African diasporic identities in America, to say that her experiences in the novel would prove true to all black women in America is denying the heterogeneity of diverse identities within the community. A narrative that relies on the essence, i.e "the invariable and fixed properties which define the 'whatness' of a given entity"(Fuss xi) may obstruct the manifestation of a multifaceted representation.

In a study done by Vanessa King and Dieynba Niabaly, where they interviewed twelve women who were either African or African-American with either chemically treated or natural hair, they found several different factors of motivation behind their hair choices, with a significant difference in experience and influence between African and African-American women, " $(t)$ his emphasizes the need to recognize African and African American ethnicities as distinct groups that have different cultural practices, different history and thus different factors that shape their experiences." (King, and Niabaly, 16). While shared socio-political history may undoubtedly bind a certain racial or ethnic group together, other factors like location, culture, environment, and personal experiences need to be considered beyond the monolithic identification based on a single affinity. In the case of Americanah (2013), location plays an important determinant for the changing attitudes toward the complexities of race and identity. The nature of race changes as Ifemelu travels beyond boundaries, as she told Curt "(r)ace doesn't really work here. I feel like I got off the plane in Lagos and stopped being black" (Adichie, 476). In her blog post titled "To My Fellow NonAmerican Blacks: In America You Are Black, Baby', Ifemelu explores this changing dynamics and the weight of blackness in America that is often foreign to a non-American black person. Unlike their homelands, they are not allowed the choice to ignore their blackness in America. The lengths of adjustment needed for a non-American black to live in America, as described by Ifemelu, is a testament to the insufficiency of a single narrative to analyse black identities.

Through an exploration of the experiences of migration and the sense of loss and displacement that accompany it, Americanah (2013) delves into the complexities of race and the impact of location and environment on identity. The protagonist in the novel has her life completely overturned by her expatriation to the U.S, where her idealised concept of this new world is challenged by an inhospitable reality. Tracing Ifemelu's physical journey across nations, as well as her psychological journey symbolized through hair, we get to observe the relationship between the mental and the physical, the surrounding and the psyche. This inquiry into the complex mechanism and intersectionality of several structures challenges the mode of analyzing difference from a single vector. 


\section{References}

Adichie, Chimamanda Ngozi. 2013. Americanah. Harper Collins Publishers Inc.

Adichie, Chimamanda Ngozi. 2016. Interview by Ashley Weatherford. "Chimamanda Adichie Black Hair and the Narrow Definition of Beauty". The Cut. 8 December 2016, www.thecut.com/2016/12/chimamanda-adichie-on-black-hair-and-redefining-beauty.html, Accessed 5 February 2019.

Byrd, Ayana D., and Lori L. Tharps. 2014. Hair Story: Untangling the Roots of Black Hair in America. Revised ed., St. Martin's Griffin.

Clifford, James. 1994. "Diasporas". Cultural Anthropology. vol. 9, no. 9, pp. 302-338.

Fuss, Diana. 1989. Essentially Speaking: Feminism, Nature E Difference. Routledge.

Johnson, Tabora A., and Teiahsha Bankhead. 2014 . "Hair It Is: Examining the Experiences of Black Women with Natural Hair.” Open Journal of Social Sciences, vol. 02, no. 01, 2014, pp. 86-100., doi:10.4236/jss.2014.21010.

King, Vanessa, and Dieynaba Niabaly. 2013. “The Politics of Black Women's Hair”. Journalof Undergraduate Research at Minnesota State University, Mankato. vol. 13, no. 4, 2013, pp 1-19.

Mami, Fouad. 2014. "Circumventing Cultural Reifications: A Study of Chimamanda Ngozi Adichie's The Thing Around Your Neck". Romanian Journal of English Studies. vol. 11, no. 1, 2014. pp. 215-225.doi: 10.2478/rjes-2014-0025. Accessed 20 December 2018.

Palmer, Collin A. 200o. "Defining and Studying the Modern African Diaspora”. Journal of Negro History. Vol. 85, no. 1/2. pp 27-32. JSTOR, www.jstor.org/stable/2649097.

Safran, William. "Diasporas in Modern Societies: Myths of Homeland and Return.”

Diaspora. vol. 1, no. 1, 1991. pp. 83-99.

Dr. Shuchi, is an Assistant Professor in the Department of Basic Sciences and Humanities \& Social Sciences at National Institute of Technology Mizoram, Aizawl, Mizoram, India.

Josephine Ramdinmawii Zote- is a research scholar in the Department of Basic Sciences and Humanities \& Social Sciences at National Institute of Technology Mizoram, Aizawl, Mizoram, India. 